\title{
Regional Climate Response Collaboratives: Multi-institutional Support for Climate Resilience
}

Kristen Averyt ${ }^{1,2,3, *}$, Justin D. Derner ${ }^{4,5}$, Lisa Dilling ${ }^{1,2 * *}$, Rafael Guerrero, ${ }^{4,6}$, Linda Joyce $^{4,7}$, Shannon McNeeley ${ }^{8}$, Elizabeth McNie ${ }^{1,2, *}$, Jeffrey Morisette ${ }^{9, *}$, Dennis Ojima $^{8,10}$, Robin O’Malley ${ }^{8,9}$, Dannele Peck ${ }^{4,5}$, Andrea J. Ray ${ }^{1,11}$, Matt Reeves ${ }^{4,7}$, William Travis $^{1,2}$

$7 \quad{ }^{1}$ Western Water Assessment, University of Colorado Boulder

$8 \quad{ }^{2}$ University of Colorado Boulder

$9 \quad{ }^{3}$ Now at Desert Research Institute, Reno Nevada

${ }^{4}$ U.S. Department of Agriculture Northern Plains Climate Hub

${ }^{5}$ U.S. Department of Agriculture Agricultural Research Service

${ }^{6}$ U.S. Department of Agriculture Natural Resources Conservation Service

${ }^{7}$ U.S. Department of Agriculture Forest Service

${ }^{8}$ U.S. Department of Interior, North Central Climate Science Center

${ }^{9}$ U.S. Geological Survey

${ }^{10}$ Colorado State University

${ }^{11}$ National Oceanic and Atmospheric Administration, Earth Systems Research

*Current affiliations: Averyt: Desert Research Institute, Reno, Nevada; McNie: Invasive Species Council Secretariat, U.S. Department of the Interior, Fort Collins, Colorado

**Correspondence to: ldilling@colorado.edu

Corresponding Author Full Contact information: Lisa Dilling, ldilling@colorado.edu, 303-735-3678, Environmental Studies Program, 4001 Discovery Drive UCB 397

University of Colorado Boulder 80309

Editorial Note: During the preparation and review of this article, Congressional action resulted in a name change for one of the institutions discussed here. Climate Science Centers (CSC) will in the future be known as Climate Adaptation Science Centers. This name change went into effect just as we went to press so we have used the old name in the body of the article. 
33 Abstract: Federal investments by U.S. agencies to enhance climate resilience at regional 34 scales grew over the past decade (2010s). To maximize efficiency and effectiveness in 35 serving multiple sectors and scales, it has become critical to leverage existing agency36 specific research, infrastructure, and capacity while avoiding redundancy. We discuss

37 lessons learned from a multi-institutional "regional climate response collaborative" that 38 comprises three different federally-supported climate service entities in the Rocky

39 Mountain west and northern plains region. These lessons include leveraging different

40 strengths of each partner, creating deliberate mechanisms to increase cross-entity

41 communication and joint ownership of projects, and placing a common priority on

42 stakeholder-relevant research and outcomes. We share the conditions that fostered

43 successful collaboration, which can be transferred elsewhere, and suggest mechanisms

44 for overcoming potential barriers. Synergies are essential for producing actionable

45 research that informs climate-related decisions for stakeholders and ultimately enhances

46 climate resilience at regional scales. 
Climate variability and change affect society across numerous sectors at multiple

48 spatiotemporal scales. New demands for information and decision support tools to enhance climate resilience at regional scales have prompted diverse agency investments over the past decade (2010s). Here, we discuss lessons learned from a regional climate response collaborative comprised of three different climate-service entities and using a multi-institutional approach. These entities have defined roles and responsibilities in terms of the agency missions and expectations, the landscapes they work in, and their

54 stakeholders, but are also linked together by common elements such as climate

55 information needs, shared water resources, and intersecting socio-economic systems. We can now draw on agencies’ experiences to understand how best to leverage existing research, infrastructure, and capacity (personnel and resources) to maximize effectiveness while avoiding redundancy.

No single entity has the exclusive mandate or resources to deliver climate services (for more background see NRC 2009). Instead, the institutional capacity for understanding climate variability, stakeholder needs, experimental tool development, technology transfer, and options for adaptation to climate variability and change has been built by many entities over the years. A thorough discussion of the myriad of entities’ contributions to regional capacity building over the preceding years is beyond the scope of this paper. However, some example organizations include the Regional Climate Centers (RCCs), State Climate Offices, NOAA Regional Climate Services Directors, National Drought Mitigation Center (NDMC) and Landscape Conservation Cooperatives 
(LCCs). ${ }^{1}$ The National Integrated Drought Information System (NIDIS) is a relative newcomer to the space, but has brought new capacity and resources for regional drought early warning systems (DEWs). Dilling et al. (2015) provide further analysis of how decision support capacity intersects with regional climate-related needs.

Our focus here is on a collaboration among entities located within the Rocky Mountain West and Northern Plains region, which have been supported by the Department of Commerce through the National Oceanic and Atmospheric Administration (NOAA), the Department of Interior (DOI), and the U.S. Department of Agriculture (USDA). NOAA established the first University-based Regional Integrated Sciences and Assessment (RISA) program in the U.S in 1995; its mission is to "help expand and build the nation's capacity to prepare for and adapt to climate variability and change.” RISAs work across a variety of contexts and focus on enhancing the use of science in decision making and building resilience to extreme events in urban and rural areas, such as drought and coastal flooding. The DOI followed suit in 2009, establishing regionally focused Climate Science Centers (CSCs) through Secretarial Order 3289. CSCs are tasked with providing robust climate science to support DOI agencies (National Park Service, U.S. Fish and Wildlife Service, Bureau of Land Management, Bureau of Reclamation, Bureau of Indian Affairs) that manage Departmental land, water, fish, wildlife, and cultural heritage resources. CSCs also work closely with DOI LCCs and state fish and wildlife agencies. Then, in 2014, the USDA organized 10 Climate Hubs

\footnotetext{
${ }^{1}$ An acronym list can be found in Table 1.
} 
$(\mathrm{CH})$ to develop and deliver science-based, region-specific information and technologies to farmers, ranchers and foresters that enable climate-smart decision-making. The Hubs' work includes directing constituents to USDA programs that may provide technical and financial assistance. Taken together, there are 26 different RISA, CSC, and CH entities across the U.S., each with a unique geographic purview.

This paper highlights a regional climate response collaborative located in the Rocky Mountain West and Northern Plains that comprises three entities: Western Water Assessment (WWA), North Central Climate Science Center (NCCSC), and Northern Plains Climate Hub (NPCH). For 19 years, NOAA has supported WWA, a RISA Program based at the University of Colorado Boulder covering a three-state region ${ }^{2}$. WWA is primarily a research unit that focuses on how to make climate information more usable at regional scales. With strengths in hydrology, climate science, and decision science, WWA has strong ties with water resource managers.

The NCCSC opened its doors in 2011 to serve DOI land managers within a sevenstate region ${ }^{3}$. As a university-agency partnership ${ }^{4}$, similar to WWA, the NCCSC leverages academic research and extensive U.S. Geological Survey (USGS) capabilities to bring the best climate science to federal land managers, state wildlife agencies, and tribal resource managers. NCCSC also provides opportunities for university and USGS researchers to engage with decision-makers.

\footnotetext{
${ }^{2}$ Colorado, Utah and Wyoming

${ }^{3}$ North Dakota, South Dakota, Nebraska, Kansas, Colorado, Wyoming, Montana

${ }^{4}$ Hosted by Colorado State University in collaboration with 8 additional universities in the region at the time this paper was written.
} 
108 information and decision-support tools to farmers, ranchers, forest landowners, and tribes

109 striving to adapt to climate variability in a six-state region. ${ }^{5} \mathrm{NPCH}$ also serves as a

110 messenger in collaboration with the land grant Cooperative Extension for working-land

111 managers, relaying their weather or climate-related concerns and ideas back to USDA,

112 WWA, NCCSC, and other partners.

These three entities’ geographic regions do not overlap perfectly with each other,

114 so the examples presented here focus on collaborative projects where geographic overlap

115 does occur, primarily in northern Colorado and Wyoming. Successful collaborative

116 efforts in this region include the following, each led by one of the regional entities with

117 contributions from the others: producing the Colorado Climate Report (Lukas et al.,

118 2014), which was incorporated into the Colorado State Water Plan ${ }^{6}$; defining the

119 ecological impacts of drought (North Central Climate Science Center, 2015); capacity-

120 building and co-production of drought preparedness tools with tribes in the Wind River

121 Indian Reservation (North Central Climate Science Center, 2016), including early

122 application of a new drought indicator, the Evaporative Demand Drought Indicator,

123 (EDDI) (Rangwala et al. 2015); development of the Drought, Ranching, and Insurance

124 Response Model to inform decision-making in the region’s extensive rangeland livestock

125 industry (Western Water Assessment 2017); and an assessment of the vulnerability of

126 grazing and confined livestock to mid and late $21^{\text {st }}$ century climatic predictions (Derner et

\footnotetext{
${ }^{5}$ North Dakota, South Dakota, Nebraska, Colorado, Wyoming, Montana

${ }^{6}$ https://www.colorado.gov/cowaterplan
} 
127 al. 2017). Next we describe two of these examples in greater detail to illustrate how the

128 collaborating entities' expertise and resources are typically leveraged to serve

129 stakeholders' needs more effectively and efficiently.

130 The goal of the Wind River Drought Preparedness Project is to co-produce

131 actionable science for drought preparedness through foundational partnerships with the

132 Eastern Shoshone and Northern Arapaho tribes at Wind River Reservation (WRR),

133 NCCSC, WWA, NPCH, among many other government agencies and university partners.

134 The NCCSC established initial relationships with tribal water resource managers to co-

135 develop the project with the National Drought Mitigation Center and NIDIS, and led

136 initial studies of drought impacts and responses in the region (McNeeley and Beeton,

137 2017). Partnerships among the High Plains Regional Climate Center, NDMC, NIDIS, and

138 NCCSC have enabled the co-production of quarterly drought and climate summaries for

139 WRR and the surrounding area (Wind River Indian Reservation Drought and Climate

140 Summary). The partnership with WWA is supporting the testing of innovative drought

141 tools such as the EDDI for the WRR (Hobbins et al. 2016), and providing an overall

142 evaluation of the project. The summaries and EDDI together provide the infrastructure

143 for monitoring and early warning systems, and support decision-making on the ground.

144 All partners are working together to synthesize this information into an integrated social-

145 climate-ecological vulnerability assessment that will provide the science needed to

146 develop a reservation-wide drought management plan, while the NPCH is working

147 specifically to integrate climate information into agricultural and ranching sections of the

148 WRR Agricultural Resources Management Plan. 
A second example, the Drought, Ranching, and Insurance Response Model

150 collaborative effort, was motivated by widespread drought in 2012 (Hoerling et al., 2014), which had major impacts on the region's rangelands and triggered large reductions

152 in cattle herd numbers due to reduced forage availability and high feed prices. In response, USDA’s Agricultural Research Service (ARS) developed an on-line drought

154 calculator to help ranchers assess forage availability (Dunn et al., 2013). USDA’s Risk 155 Management Agency (RMA) also rolled out a pilot Pasture, Rangeland, Forage (PRF)

156 insurance policy for livestock producers, indexed to NOAA’s gridded precipitation

157 product (USDA Risk Management Agency, 2015). WWA brought these two USDA

158 offerings together in an integrated computer simulation model to inform livestock

159 producers' adaptation decisions in the face of drought (Derner and Augustine 2016).

160 WWA's model features a drought forage calculator based on local conditions, the cost

161 and expected profit of different drought adaptations (e.g., purchasing supplemental feed

162 vs. early marketing), and a PRF insurance calculator based on a producer's specific rainfall grid. WWA worked closely with NPCH to improve the model's representation of

164 livestock production decisions and define the range of drought management options 165 available within it. NPCH has also arranged for livestock industry experts to meet with 166 WWA to discuss, test, and improve the model. At the time of writing, both on-line and 167 down-loadable versions of the model are available on-line from WWA and it is being 168 applied in a variety of user experiments to test hypotheses about the role of insurance and 169 enhanced information in drought risk management. 
Many factors have contributed to the successful transdisciplinary efforts and

172 outcomes of this regional climate response collaborative. We look forward to further

173 refinements of on-going efforts to achieve efficient and effective working relationships at

174 a regional level to build climate resilience with targeted resources.

175

176

177

178

179

180

181

182

183

184
Lesson 1: Collaborative success of our three regional climate entities was

manifest in recognizing, appreciating and leveraging differences and synergies across regional partners (Table 2). Collectively, the three regional climate entities embrace a shared focus to address stakeholder-driven priorities with our staff's combined skills, knowledges, and experiences in scientific, technical and information-transfer.

Lesson 2: Emphasizing transdisciplinary services facilitates cross-

agency/department collaboration through regional nodes involving direct connections to each climate entity. Services offered, for example, through the USDA-supported NPCH or the Wind River Project benefit from their close collaboration with the NOAAsupported WWA's research on seasonal drought forecasting and decision-making. These stakeholder-focused collaborations enable interdisciplinary and multi-institutional efforts at regional scales, which propel science-based information into entirely new decision spheres. For example, NPCH has long-standing relationships with farmers and ranchers through USDA Service Centers, Agricultural Experiment Stations, Cooperative Extension at land grant universities and producer organizations; NCCSC has close ties with state and federal fish, wildlife and resource managers as well as tribal communities; and WWA works hand-in-hand with water resources managers and municipalities. 
193 integrated management structures fosters the building of relationships and synergistic

194 leveraging. For example, the NCCSC and NPCH share a joint stakeholder committee;

195 members of the WWA research team are imbedded within NCCSC's management

196 structure; the WWA Advisory Board includes leadership from NCCSC and NPCH; and

197 the three entities hold twice-yearly joint meetings. Regular maintenance and nurturing of

198 these connections between nodes, or "webs of connectivity,” are essential to the practical

199 functioning of our collaborative work and thus our success in serving the needs of

200 stakeholders (Vogel et al., 2007 as cited in Dilling et al., 2015).

Lesson 4: The successful collaboration benefitted from early agreement on a set

202 of common principles for delivering climate services at a regional scale (described further

203 below). Common principles can also provide guidance for other regional collaboratives

204 that may emerge in the future from other federal agencies.

\section{Common Principles}

All three organizations share a common principle of aiming to co-develop and co-

207 produce science with stakeholders to support climate-smart decision-making (Lemos and

208 Morehouse, 2005). Research and outreach agendas are therefore carefully designed to

209 optimize their relevance to stakeholder-driven priorities. Outcomes focus on an ongoing

210 process of action and adjustment, or adaptive management, rather than prescriptive

211 solutions, with active engagement of stakeholders throughout the entire effort. 
Each entity strives to remain flexible and responsive to their primary stakeholders,

213 and cognizant of the emerging or evolving regional challenges posed by extreme climate

214 events. This flexibility is made possible by an adaptive management structure, where

215 investments and divestments can be made quickly, and decisions about realignments can

216 be made strategically within the organizations themselves. An example of this flexibility

217 is an ad hoc webinar that our collaborative organized at the onset of the El Niño signal in

218 2015. Scientists from WWA presented material while the NCCSC and NPCH engaged

219 their unique sets of stakeholders for participation. The webinar resulted in a front-page

220 article in the Wyoming Livestock Roundup newspaper (a stakeholder of the NPCH;

221 Albert, 2015), and provided insights about ecological impacts, which NCCSC contributed

222 to NOAA’s Missouri Basin Region El Niño Impacts and Outlook report (NOAA, 2015).

Scientists within each entity also share a commitment to successful collaborations

224 across disciplines and institutions, and a dedication to engage with stakeholders and

225 decision-makers across socio-political divides. Members of the collaborative discuss

226 scientific and organizational failures, and share lessons learned so others can avoid

227 similar pitfalls. Communication skills are valued alongside scientific excellence.

228 Researchers often put these communication skills to use as "climate counselors,” working

229 with stakeholders to synthesize and tailor climate science information to most effectively

230 address questions at hand. This requires an emphasis on listening and communicating

231 early, often, and iteratively. Perhaps most importantly, collaborative team members

232 understand the context of climate in the scope of regional priorities and concerns because 
233 effective solutions must reflect the missions of individual entities as well as the realities

234 of our diverse stakeholder communities (Table 2).

235 All three entities endeavor to foster mutual engagement, knowledge, and trust

236 with “on-the-ground” stakeholders and decision makers that require sustained

237 commitment beyond two or three-year research projects. This necessitates a different

238 funding model and expectations for practical, two-way translation of science for effective

239 transfer of knowledge and learning, and feedback loops for iterative collaborations. This

240 regional climate response collaborative, through diversity of scientific and support staff

241 with long-term partners, facilitates more rapid and relevant dissemination of usable

242 science from collaborative efforts, through the most appropriate partner for a particular

243 project, rather than having to forge new relationships for each new decision-support

244 project.

245 Transferability to other Regions

246 Regions differ and have unique sets of leaders, sensitivities, and decision contexts

247 on the ground. Nonetheless, in addition to the lessons and principles discussed above, we

248 offer some additional thoughts specifically focused on collaboration from our own

249 experiences that may transcend regional differences and help others interested in

250 launching regional climate response collaboratives.

251 First, it is important that entities place a conscious, deliberate focus on making

252 collaboration successful for each entity as well as the larger collaborative. Collaboration

253 across agencies requires staff time, targeted financial resources (to support meetings and 
254 projects), and prioritization among many competing demands. For example, the three 255 centers' periodic retreats require management focus and funding, and since the three 256 centers rotate responsibility for these meetings, all have "skin in the game" for their 257 success.

259 which to build a more permanent and routine expectation of institutional collaboration. 260 For example, individual scientists in our organizations already had experiences working 261 together on prior research projects, which created an existing reservoir of trust and 262 common ground upon which to build. If such projects do not yet exist in a region, 263 focusing on one or two small, naturally-arising project opportunities (e.g., collaborative 264 pilot projects) is recommended prior to building a bigger regional collaborative. Third, it is important to discuss and debate up front the reasons for collaborating 266 and whether there is added value for each organization. As previously described, we had 267 a natural division of roles and responsibilities in terms of the types of landscapes we 268 worked in, the stakeholders we interacted with, and the expectations of each of our 269 agencies. Nonetheless, our landscapes and stakeholders are also linked together by 270 common elements such as climate information needs, the geographies of shared water 271 resources, and intertwined socio-economic systems (such as grazing activities that take 272 place both on private and public lands). Discussing and determining the real value-added 273 for collaboration produces a strong foundation for underpinning commitment to the 274 process. 


\section{Addressing Possible Barriers to Collaboration}

Naturally there are barriers to embarking on a regional climate response collaborative. The degree of inter-organizational interactions implied here requires significant management time and attention - a scarce resource. Time demands are often cited as key barriers, and sustained management commitment to strategies like regularly scheduled meetings are needed to ensure these efforts get their due. In addition, it is important to seek out opportunities that provide a "win” for individual entities as well as for the whole-by ensuring that the collaboration activity supports existing goals that each agency must accomplish as well as the larger goal of the regional project.

Second, because the three entities are pioneering new approaches, personnel transitions have the potential to derail forward motion. All three entities will inevitably struggle with the balance between reliance upon innovative leadership and regularizing processes to institutionalize the new ways of operating. In our case, personnel transitions have already happened in all three of our organizations, but the collaborative effort remains steadfast and new projects are being co-produced, a clear sign that the collaboration has become institutionalized.

Third, like any other collaboration across disciplinary lines, language can be a barrier, such as the use of different terminology and vernacular in different sectors. For example, most ecologists are not familiar with “cow-calf operations” and many agriculture specialists do not track “evolutionary adaptive capacity.” We emphasize joint 
296 retreats every 6 months in a casual setting that enable dialogue and presentations

297 designed to be accessible rather than "impressive.” Language barriers can be persistent

298 and attention needs to be focused on making sure that true understanding has taken place,

299 which can be time consuming.

$300 \quad$ Finally, “agency turf” can derail attempts at collaboration. In the climate services

301 landscape, however, there are many stakeholder needs in different contexts across

302 multiple spatiotemporal scales; thus many opportunities arise to be creative and unique in

303 providing usable science. Our experiences are that keenly focusing on opportunities, and

304 clearly articulating differentiated missions of organizations can mitigate turf battles.

\section{Conclusions}

Developing new ways of connecting, leveraging, and supporting regional climate

308 response collaboratives shows promise in building and improving regional climate

309 resilience. It is our experience that collaboration itself is a form of adaptive capacity that

310 enhances efficient co-production and delivery of relevant information through existing

311 networks of trusted relationships. Establishing and maintaining a diversity of partners

312 ensures that redundancy is minimized, and enables flexibilities in response to emerging

313 stakeholder and societal priorities. Further experimentation with regional strategies for

314 collaboration, co-production, and interdisciplinary communication is needed to continue

315 to strengthen climate resilience. 
317 Acknowledgments: The authors appreciate support from the DOI Climate Science

318 Centers, the USDA Climate Hubs, the Cooperative Institute for Research in

319 Environmental Sciences, the NOAA/ESRL Physical Sciences Division and a grant from

320 the NOAA Regional Integrated Sciences and Assessment Program to the Western Water

321 Assessment (NA10OAR4310214). Any use of trade, product, or firm names is for

322 descriptive purposes only and does not imply endorsement by the U.S. Government.

323 


\section{For Further Reading:}

325 Albert, S., Wyoming Livestock Roundup, 2014: El Nino impacts predicted to influence

326 warm, dry winter in West. Accessed 20 September 2016. [Available online at

327 http:/www.wylr.net/water/188-weather/5659-el-nino-impacts-predicted-to-influence-

328 warm-dry-winter-in-west.]

329

330 Derner, J.D., and D.J. Augustine. 2016. Adaptive management for drought on rangelands.

331 Rangelands 38:211-215.

332

333 and D. Peck. 2017. Vulnerability of grazing and confined livestock in the Northern Great

336 Plains to projected mid- and late- $21^{\text {st }}$ century climate. Climatic Change (in press)

Dilling L., K. Lackstrom, B. Haywood, K. Dow, M.C. Lemos, J. Berggren, and S.

339 Kalafatis, 2015: What stakeholder needs tell us about enabling adaptive capacity: the 340 intersection of context and information provision across regions in the United States.

341 Weather, Climate, and Society. 7(1), 5-17, doi:10.1175/WCAS-D-14-00001.1

343 Dunn, G.H., M. Gutwein, L.J. Wiles, T.R. Green, A. Menger, and J. Printz, 2013. The 344 drought calculator: decision support tool for predicting forage growth during drought. 345 Rangeland Ecology and Management. 66(5):570-578, doi:10.2111/REM-D-12-00087.1 
Hobbins, M., Wood, A., McEvoy, D., Huntington, J., Morton, C., Verdin, J., Anderson, M., Hain, C. (2016). The Evaporative Demand Drought Index: Part I-Linking Drought Evolution to Variations in Evaporative Demand. Journal of Hydrometeorology, 17, 1745-1761. https://doi.org/10.1175/JHM-D-15-0121.1

Hoerling, M., J. Eischeid, A. Kumar, R. Leung, A. Mariotti, K. Mo, S. Schubert, and R. Seager, 2014: Causes and predictability of the 2012 Great Plains drought. Bulletin of the American Meteorological Society. 95, 269-282, doi:10.1175/BAMS-D-13-00055.1

Lemos, M.C., and B. J. Morehouse, 2005: The co-production of science and policy in integrated climate assessments. Global Environmental Change. 15, 57-68, doi:10.1016/j.gloenvcha.2004.09.004

Lukas, J., J. Barsugli, N. Doesken, I. Rangwala, and K. Wolter, 2014: Climate Change in Colorado: A Synthesis to Support Water Resources Management and Adaptation. (Western Water Assessment, University of Colorado Boulder).

McNeeley, S.M., Beeton, T.A., 2017. Wind River Reservation: Drought Risk and Adaptation in the Interior (DRAI) report. A draft report for The Wind River Indian Reservation's Vulnerability to the Impacts of Drought and the Development of Decision Tools to Support Drought Preparedness. North Central Climate Science Center, Fort Collins, CO. 
369 NOAA, 2015: High Plains Regional Climate Center. Accessed 20 September 2016.

370 [Available online at http://www.drought.gov/media/pgfiles/ENSO-MOBasin-2015-

$371 \quad$ Final.pdf.]

372

373 North Central Climate Science Center, 2016: The Wind River Indian Reservation's

374 vulnerability to the impacts of drought and the development of decision tools to support

375 drought preparedness. Accessed 20 September 2016. [Available online at

376 http://revampclimate.colostate.edu/revamp/project/wind-river-drought-preparedness]

377

378 North Central Climate Science Center, 2015: Ecological Drought in the North Central

379 United States. Accessed 11 June 2017. [Available online at

380 http://ian.umces.edu/pdfs/ian_newsletter_504.pdf]

National Research Council. 2009: Restructuring Federal Climate Research to Meet the Challenges of Climate Change. National Academies Press, 254 pp.

382 Rangwala, I., M. Hobbins, J. Barsugli, and C. Dewes, 2015: EDDI-A Powerful Tool for 383 Early Drought Warning. Accessed 24 June 2017. [Available online at 384 http://wwa.colorado.edu/publications/reports/EDDI_2-pager.pdf] 
386 USDA Risk Management Agency, 2015: Pasture, Rangeland, Forage Pilot Insurance

387 Program. Accessed 24 June 2017. [Available online at

388 https://www.rma.usda.gov/pubs/rme/prfinsprog.pdf]

389

390 Western Water Assessment, 2017: Drought Decision Analysis. Accessed 11 June 2017.

391 [Available online at

392 http://wwa.colorado.edu/themes/projects/drought_decision_analysis.html]

393

394 Wind River Indian Reservation (WRIR) Climate and Drought Summary. Accessed

395 October 10, 2017. [Available online at: http:// http://tribalwaterengineers.org/ see tab

396 under "Projects” and “Drought Mitigation Projects”] 
Table 1: Acronyms used in text.

\begin{tabular}{|l|l|}
\hline Acronym & Entity \\
\hline ARS & Agricultural Research Service (USDA) \\
\hline CH & Climate Hub (USDA) \\
\hline CSC & Climate Science Center (DOI) \\
\hline DEWS & Drought Early Warning System (NIDIS) \\
\hline DOI & Department of the Interior (DOI) \\
\hline EDDI & Evaporative Demand Drought Indicator \\
\hline LCC & Landscape Conservation Cooperatives (DOI) \\
\hline NCCSC & North Central Climate Science Center (DOI) \\
\hline NDMC & National Drought Mitigation Center \\
\hline NIDIS & National Integrated Drought Information System (NOAA) \\
\hline NOAA & National Oceanic and Atmospheric Administration \\
\hline NPCH & Northern Plains Climate Hub (USDA) \\
\hline PRF & Pasture, Rangeland, Forage \\
\hline RCC & Regional Climate Center (NOAA) \\
\hline RISA & Regional Integrated Sciences and Assessments (NOAA) \\
\hline RMA & Risk Management Agency (USDA) \\
\hline USDA & Department of Agriculture \\
\hline USGS & US Geological Survey (DOI) \\
\hline WRIR & $\begin{array}{l}\text { Wind River Indian Reservation (Used } \\
\text { for Drought and Climate Outlook } \\
\text { Summary) }\end{array}$ \\
\hline WRR & Wind River Reservation \\
\hline WWA & Western Water Assessment (RISA) \\
\hline
\end{tabular}


Table 2. Characteristics of the federally-supported Regional Climate Response

405 Collaborative in the Northern Plains \& Rocky Mountain West.

\begin{tabular}{|c|c|c|c|}
\hline & $\begin{array}{c}\text { Western Water } \\
\text { Assessment }\end{array}$ & $\begin{array}{c}\text { North Central } \\
\text { Climate Science } \\
\text { Center }\end{array}$ & $\begin{array}{l}\text { Northern Plains } \\
\text { Climate Hub }\end{array}$ \\
\hline $\begin{array}{l}\text { Supporting } \\
\text { Agency \& } \\
\text { Program }\end{array}$ & $\begin{array}{l}\text { National Oceanic } \\
\text { and Atmospheric } \\
\text { Administration } \\
\text { (NOAA) }\end{array}$ & $\begin{array}{l}\text { Department of } \\
\text { Interior (DOI), U.S. } \\
\text { Geological Survey }\end{array}$ & $\begin{array}{l}\text { U.S. Department of } \\
\text { Agriculture } \\
\text { (USDA) }\end{array}$ \\
\hline $\begin{array}{l}\text { Primary } \\
\text { Users, } \\
\text { Stakeholders, } \\
\text { Constituents }\end{array}$ & $\begin{array}{l}\text { Federal, municipal, } \\
\text { regional, } \\
\text { residential; Water } \\
\text { resource managers }\end{array}$ & $\begin{array}{l}\text { Department of } \\
\text { Interior, state land } \\
\text { managers, and tribal } \\
\text { environmental } \\
\text { professionals }\end{array}$ & $\begin{array}{l}\text { Agricultural and } \\
\text { natural resource } \\
\text { managers; ranchers, } \\
\text { farmers, forest land } \\
\text { owners }\end{array}$ \\
\hline Sectoral Focus & $\begin{array}{l}\text { Water resources, } \\
\text { urban, hazards, } \\
\text { science policy }\end{array}$ & $\begin{array}{l}\text { Wildlife, wildland, } \\
\text { tribal }\end{array}$ & $\begin{array}{l}\text { Agriculture and } \\
\text { forestry }\end{array}$ \\
\hline $\begin{array}{l}\text { Annual Direct } \\
\text { Agency } \\
\text { Support } \\
\end{array}$ & $\$ 700 \mathrm{k}$ & $\$ 2.0 \mathrm{M}$ & $\$ 475 \mathrm{k}$ \\
\hline Start Year & 1999 & 2011 & 2014 \\
\hline Mission & $\begin{array}{l}\text { To conduct } \\
\text { innovative research } \\
\text { and engagement } \\
\text { aimed at effectively } \\
\text { and efficiently } \\
\text { incorporating } \\
\text { knowledge into } \\
\text { decision making in } \\
\text { order to advance the } \\
\text { ability of regional } \\
\text { and national entities } \\
\text { to manage climate } \\
\text { impacts. }\end{array}$ & $\begin{array}{l}\text { To provide the best } \\
\text { possible climate } \\
\text { science to DOI land } \\
\text { managers \& provide } \\
\text { university and } \\
\text { USGS researchers } \\
\text { an opportunity to } \\
\text { work with an } \\
\text { engaged and } \\
\text { proactive applied } \\
\text { management } \\
\text { community. }\end{array}$ & $\begin{array}{l}\text { To develop and } \\
\text { deliver science- } \\
\text { based, region- } \\
\text { specific information } \\
\text { and technologies } \\
\text { that enable } \\
\text { agricultural and } \\
\text { natural resource } \\
\text { managers to make } \\
\text { climate-informed } \\
\text { decisions, and to } \\
\text { provide access to } \\
\text { assistance for } \\
\text { implementing those } \\
\text { decisions. }\end{array}$ \\
\hline $\begin{array}{l}\text { Geographic } \\
\text { Focus }\end{array}$ & UT, WY, CO & $\begin{array}{l}\text { Upper Missouri } \\
\text { Basin (MT, ND, } \\
\text { WY, NE, SD, CO, } \\
\text { KS) }\end{array}$ & $\begin{array}{l}\text { Northern Plains } \\
\text { (ND, SD, NE, MT, } \\
\text { WY, CO) }\end{array}$ \\
\hline
\end{tabular}




\begin{tabular}{|c|c|c|c|}
\hline $\begin{array}{l}\text { Temporal } \\
\text { Focus }\end{array}$ & Seasonal to 2100 & $\begin{array}{l}\text { DOI and Tribal } \\
\text { management } \\
\text { planning horizons }\end{array}$ & $\begin{array}{l}\text { Working-lands } \\
\text { management } \\
\text { planning horizons } \\
\text { (days to decades) }\end{array}$ \\
\hline $\begin{array}{l}\text { Research to } \\
\text { Application } \\
\text { Mode }\end{array}$ & $\begin{array}{l}\text { Research focus } \\
\text { informed by needs } \\
\text { of decision makers }\end{array}$ & $\begin{array}{l}\text { Research and } \\
\text { applied }\end{array}$ & $\begin{array}{l}\text { Some applied } \\
\text { research; greater } \\
\text { emphasis on } \\
\text { transfer of } \\
\text { information and } \\
\text { tools to end-users }\end{array}$ \\
\hline $\begin{array}{l}\text { Research to } \\
\text { Application } \\
\text { Process }\end{array}$ & $\begin{array}{l}\text { Co-production } \\
\text { using } \\
\text { interdisciplinary } \\
\text { research teams }\end{array}$ & $\begin{array}{l}\text { Foundational } \\
\text { science with client } \\
\text { requirements }\end{array}$ & $\begin{array}{l}\text { Direct working-land } \\
\text { managers to tools } \\
\text { and USDA } \\
\text { programs that may } \\
\text { provide technical } \\
\text { and financial } \\
\text { assistance to reduce } \\
\text { risk and increase } \\
\text { resilience }\end{array}$ \\
\hline $\begin{array}{l}\text { Operations } \\
\text { and Staff }\end{array}$ & $\begin{array}{l}\text { University Director; } \\
\text { program manager; } \\
\text { two regional } \\
\text { engagement experts }\end{array}$ & $\begin{array}{l}\text { USGS Director \& } \\
\text { University Director; } \\
\text { USGS staff; } \\
\text { University } \\
\text { researchers }\end{array}$ & $\begin{array}{l}\text { USDA ARS } \\
\text { Director, Fellow \& } \\
\text { Liaison; University } \\
\text { coordinator; support } \\
\text { of FS and NRCS } \\
\text { staff }\end{array}$ \\
\hline $\begin{array}{l}\text { Federal- } \\
\text { University } \\
\text { Partnership }\end{array}$ & $\begin{array}{l}\text { Single University } \\
\text { with NOAA ESRL }\end{array}$ & $\begin{array}{l}\text { University } \\
\text { consortium (9) with } \\
\text { USGS's National } \\
\text { Climate Change } \\
\text { Wildlife Science } \\
\text { Center (NCCWSC) }\end{array}$ & $\begin{array}{l}\text { USDA } \\
\text { collaborations with } \\
\text { Cooperative } \\
\text { Extension and } \\
\text { Agricultural } \\
\text { Experiment Stations } \\
\text { at Land Grant } \\
\text { Universities (6) }\end{array}$ \\
\hline $\begin{array}{l}\text { Funding } \\
\text { Model }\end{array}$ & $\begin{array}{l}\text { Through NOAA } \\
\text { OAR }\end{array}$ & $\begin{array}{l}\text { Through USGS } \\
\text { NCCWSC }\end{array}$ & $\begin{array}{l}\text { Through six USDA } \\
\text { agencies }\end{array}$ \\
\hline $\begin{array}{l}\text { Stakeholder } \\
\text { Advisory } \\
\text { Committee }\end{array}$ & $\begin{array}{l}\text { Eight members } \\
\text { from academia, } \\
\text { federal agencies, } \\
\text { non-profit sectors }\end{array}$ & $\begin{array}{l}\text { Federal employees } \\
\text { and Tribal } \\
\text { representative, run } \\
\text { jointly with the } \\
\text { NPCH }\end{array}$ & $\begin{array}{l}\text { Federal employees } \\
\text { and Tribal } \\
\text { representative, run } \\
\text { jointly with the } \\
\text { NCCSC }\end{array}$ \\
\hline $\begin{array}{l}\text { Core scientific } \\
\text { strengths }\end{array}$ & $\begin{array}{l}\text { Hydrology, climate } \\
\text { modeling, } \\
\text { paleoclimate, }\end{array}$ & $\begin{array}{l}\text { Ecosystems and } \\
\text { ecological } \\
\text { modeling, remote }\end{array}$ & $\begin{array}{l}\text { Agricultural } \\
\text { production, soil \& } \\
\text { crop science, }\end{array}$ \\
\hline
\end{tabular}




\begin{tabular}{|l|l|l|l|}
\hline & $\begin{array}{l}\text { decision science, } \\
\text { evaluation, usable } \\
\text { science }\end{array}$ & $\begin{array}{l}\text { sensing, public and } \\
\text { tribal lands, } \\
\text { decision support }\end{array}$ & $\begin{array}{l}\text { rangelands, systems } \\
\text { modeling, } \\
\text { adaptation } \\
\text { strategies, } \\
\text { management } \\
\text { practices, social } \\
\text { sciences }\end{array}$ \\
\hline
\end{tabular}

406 